\title{
A New Look at School Enrolment in Ghana: A Statistical Analysis
}

\author{
Ferdinand Ahiakpor \\ Lecturer, Department of Economics, University of Cape Coast, Cape Coast \\ Tel: 233-20-088-7146Ｅ-mail: fahiakpor@gmail.com \\ Jacob Nunoo \\ Lecturer, Department of Economics, University of Cape Coast, Cape Coast, \\ Tel: 233-209285638Ｅ-mail: jacnunoo@gmail.com \\ Samuel E. Alnaa (Corresponding author) \\ Lecturer, Department of Accountancy, Bolgatanga Polytechnic, Bolgatanga \\ Tel: 233-20-666-3739 E-mail: sam.alnaa@gmail.com
}

$\begin{array}{rrr}\text { Received: March 5, } 2014 & \text { Accepted: April 8, } 2014 \quad \text { Published: May 1, } 2014 \\ \text { doi:10.5296/jse.v4i2.5242 } & \text { URL: http://dx.doi.org/10.5296/jse.v4i2.5242 }\end{array}$

\begin{abstract}
This paper assesses the determinants of school enrolment in Ghana during the period from 1970-2012 using data from World Bank Development Indicators. The study employed the Bayesian Moving Average model (BMA) in order to address the issue of model uncertainty. By making use of 28 regressors as possible determinants of school enrolment, the results of the empirical analysis show that percentage of female teachers in the community, number of schools in the community, household expenditure, labour force with primary education, progression rate to secondary level. Among others are the factors that influence enrolment level. The results are robust with the change of coefficient priors in the estimated model. Government should introduce the quota system where more females will be trained as teachers and also introduce more programmes to reduce fertility rate.
\end{abstract}

Keywords: Bayesian moving averaging, Education, Human capital, School enrolment, Ghana

JEL Classification: I20, J24, D91 


\section{Introduction}

Problems of uncertainty are inherent in economic models used to assess the determinants of school enrolment. No known empirical studies exit that have actually addressed this issue. This paper adopted Bayesian Moving Average (BMA) to deal with the issue of model uncertainty by mixing over the different models using a combination of posterior parameter and model probabilities (Raftery, A.E., D. Madigan, \& Hoeting, J. A., 1997).

The importance of education and human capital formation in fostering economic growth and development of less developed countries cannot be overemphasized. It has been shown that education and skills acquisition has positive effects on economic growth and development (Schultz, 1961; Dickens W. T., Sawhill I. \& Tebbs J., 2006). Therefore, investments in children's education is the main avenue for human resource development and capital accumulation required for building long- term productive capacity of a country. It is, therefore, essential that a country provide perfect environment for unfettered access to knowledge and skills that would increase the future productivity of children.

In spite of the documented positive impact of education and quality of life indicators, household resource allocation on education remains low in developing economies as compared to the advanced economies, due largely to parents' perceived uncertainty of returns associated with education in developing countries as a result of economic imperfections. Glick and Sahn (2000) note that lack of job opportunities in developing economies for the educated has resulted in low school enrolment and also widened the income inequality gap between advanced and developing economies.

In an attempt to plug the gap in school enrolment and achieve full school enrolment in the country Ghana, especially at the basic level, various policies have been adopted, all aimed at encouraging school enrolment. For example, the 1961 Act (Act 87) initiated by Dr. Kwame Nkrumah, the first president of Ghana, was aimed at achieving Free Universal Primary Education (FUPE). The policy made formal education accessible to all, especially the poor and those in rural areas of the country. In addition to this policy, the Vision 2020 Document (a government projected plan) also made a case for free Compulsory Universal Basic Education (fCUBE) in the country. Other government - backed schemes such as the Capitation Grant (CG), the School Feeding Programme (SFG) and the Free School Uniform Programme (FSUP), (launched from the 1980s) were all geared towards making formal education accessible to all. This means that, (given that in Ghana, the government is the main provider of education) investments in education depend on the budgetary resources available to the government, which in turn are linked to overall economic performance. Economic decline can lead to reduced government expenditures on education, and consequently reduce school enrollments, even when the proportion of the public budget allocated to the education sector does not change. This was evident in the late 1970s when the economy experienced rapid deterioration.

For the past decade, there have been a lot of empirical studies on what determines school enrolment. Kirchsteiger and Sebald (2010), on the study of investment in education indicated that the education of adults in a household has a significant impact on the enrollment of 
children in all countries studied while the effect of female adult education was larger than that of males in some countries. Connelly and Zhen (2003) studied the determinants of school enrollment and completion in China and found that parental education, country level income and village level income also affect enrollment level. In addition, the presence of first and second cycle institutions in the community are was also found to have a significant effect on enrollment. This is because when there is available schools in the area that can absorb pupils when they graduated from the primary level, parent are also encourage to enroll them in school. Also, Mutangadura and Lamb (2003) found government expenditure on education, GNP per capita, and debt categories as the main factors that influence primary school enrolment.

Schultz (1993) and Basu (1999) found direct costs associated with education, such as fees, books, and uniforms and also the opportunity cost (money parents lose when the child is in school without working for them) of the child being in school as the main factors influencing school enrolment. In addition, Glick \& Sahn (2000) found that besides the parents' income, occupation and education of the parents also collate to school enrollment. Again, parents with better education were found to have a positive impact on the number of children enrolled school (Måns, 2006; Smits \&Gündüz, 2006; Ersado, 2005; UNESCO, 2004; Buchmann \& Brakewood, 2000; Becker \&Tomes, 1976).

The gender of the household head has also been found to be a relevant influence on investments in children's education. Lloyd and Blanc (1996) concluded that female heads of households spent a larger percentage of the household budget on children than do male heads. Huisman and Smit (2009) studied households and district-level determinants of primary school enrollment in 30 developing countries using multilevel analysis. In that study, perental decisions regarding children's education were found to be influenced by socioeconomic and demographic household characteristics and characteristics of the available educational facilities, like number of teachers, percentage of female teachers, and distance to school.

Moreover, Glewwe and Jacoby (1994) in their study of factors that determined school attainment, found economic growth, provision of blackboards and repairing of leaking roofs as some of the factors that influence school enrollment. While it is a matter of empirical analysis to investigate which of the policy variables have been successful in promoting school enrollment in Ghana, there is, however, uncertainty inherent to the economic model that should be used to assess the covariates or determinants of school enrolment. It is in this context that this paper makes use of the Bayesian Model Averaging (BMA) model to determine the covariates of school enrolment in Ghana. The BMA deals with the issue of model uncertainty by combining different models using a combination of posterior parameter and model probabilities (Raftery, A.E., D. Madigan, \& Hoeting, J. A., 1997). In doing so, the BMA provides a natural solution to deal with the plethora of drivers and thus, remedy to the use of a single model and few explanatory variables to determine school enrolment in the country.

\section{Model specification}

The rationale of the BMA approach is that for a given linear model with a large number of explanatory variables $(\mathrm{k})$, there are $2^{\mathrm{k}}$ possible models, which can be obtained by the 


\section{Macrothink}

selection of explanatory variables. Appropriate models with high likelihood are obtained by averaging across the large set of models and selecting variables which are relevant to the data generating process for a given set of parameter and model priors used (Raftery et al., 1997 and Fernandez, Ley \& Steel, 2001). Parameter and model sampling in the context of the BMA approach is conducted with the aid of the Markov Chain Monte Carlo Model composition $\left(\mathrm{MC}^{3}\right)$. The $\mathrm{MC}^{3}$ method is used to indicate which model should be considered in computing the sums of posterior model and parameter probabilities by identifying the model with high posterior probability.

Given a linear regression model with $\boldsymbol{\beta}_{i}$ parameters and $i=\mathbf{0}, \mathbf{1}, \mathbf{2}, \ldots, \boldsymbol{k}$. with $\boldsymbol{k}$ explanatory variables $x_{1}, x_{2}, x_{3}, \ldots, x_{k}$, the general form of the regression is

$$
y=\beta 0+\sum_{i=1}^{k} \beta_{i} x_{i}+\varepsilon
$$

Given $k$ explanatory variables, there is a possibility of $2^{k}$ models to be obtained with the different combination of explanatory variables. The posterior distribution of the parameters $\boldsymbol{\beta}_{i}$, given the data $\mathrm{D}$, is an average of the posterior distribution of parameters under each model with weights given by the posterior model probabilities expressed as

$$
P\left(\beta_{i} / D\right)=\sum_{j=1, \beta_{i} \in M j}^{2^{k}} P\left(\beta_{i} / M_{J}\right) P\left(M_{j} / D\right)
$$

The posterior model probability, $P\left(M_{J} / D\right)$ is given by

$$
P\left(M_{j} / D\right)=\frac{l_{D}\left(M_{j}\right) P\left(M_{j}\right)}{\sum_{h=1}^{2^{k}} l_{D}\left(M_{h}\right) P\left(M_{h}\right)}
$$

Where $l_{D}\left(M_{j}\right)$ is the marginal likelihood of the model $M_{j}$ which is expressed as

$$
l_{D}\left(M_{j}\right)=\int p\left(D / \beta_{i}, M_{j}\right) p\left(\beta_{i}\right) p\left(\beta_{i} / M_{j}\right) d \beta_{i}
$$

where $P\left(D / \beta_{i}, M_{j}\right)_{\text {represents the sampling model corresponding to Equation 1. } P(\boldsymbol{\beta} i / M j)}$ is a prior probability distribution assigned to the parameters of model ${ }^{M_{j}}$, and $P\left(\beta_{i}\right)_{\text {is }}$ the 


\section{Mll Macrothink}

Journal of Studies in Education

ISSN 2162-6952

2014, Vol. 4, No. 2

improper non- informative prior for the parameters that are common to all models. The Zellner's g-prior is the preferred choice of prior structure for the regression parameters in most BMA applications. The common improper non- informative g-prior structure for $\boldsymbol{P}(\boldsymbol{\beta} \boldsymbol{i})$ is often expressed as

$$
P(\boldsymbol{\beta} i) \propto \sigma^{-1}
$$

where $\boldsymbol{\sigma}$ is a scale parameter which represents the standard error of the regression represented in Equation 1.

Nonetheless, Fernandez et al. (2001) proposes a g-prior for $P(\beta i / M j)$ and suggests that a uniform prior be represented as $g=1 / \max \left\{n, k^{2}\right\}$. The authors show that such a g-prior leads to reasonable results.

With regards to model probability prior $P\left(M_{J}\right)$, the proposed prior distribution in the literature of BMA refers to uniform distribution prior expressed as

$$
P\left(M_{j}\right)=p_{j,} \quad j=1,2 \ldots, 2^{k} \sum_{\text {with }}^{2^{k}} p_{j}=1
$$

Following Leamer (1978), the estimated posterior means and standard deviations of $\beta i, \hat{\boldsymbol{\beta}}$, are constructed as

$$
\begin{gathered}
E(\hat{\beta} / D)=\sum_{j=1}^{2^{k}} \hat{\beta} P\left(M_{j} / D\right) \\
V(\hat{\beta} / D)=\sum_{j=1}^{2^{k}}\left(\operatorname{Var}(\hat{\beta} / D, M j)+\hat{\beta}^{2}\right) P\left(M_{j} / D\right)-E(B / D)^{2}
\end{gathered}
$$

\section{Data}

A yearly data ranging from the period 1970 to 2012 are collected from World Bnk Development Index (WDI, 2012), Ghana Living Standard Survey (GLSS, 2008) and Ministry of Education reports. There is a total of 29 variables used in the model estimation, including the total number of school enrolments at the primary level as the dependent variable. The independent variables include: total fertility rate, HIV infection rate, annual GDP growth rate, inflation, population growth rate, level of poverty, primary school completion rate, number of repeaters in primary school.. Details of the variables used in the estimation are shown in Table A1 in the appendix. 


\section{Empirical Results and Discussion}

Table A2 present the descriptive statistics of the variables used in the study. The result shows that on average school enrolment is about $59.9 \%$ of school going aged with a minimum of $38.3 \%$ and a maximum of $91.07 \%$. In addition, the average public expenditure on education as a percentage of GDP is about $2.89 \%$ with the lowest being $0.64 \%$ and the maximum percent spend on education being $12.2 \%$ at the basic level of education. Also, the average GDP growth is 0.011 or $1.1 \%$ with a minimum of $-10 \%$ and a maximum of $14 \%$ in the year during the period 1970 to 2012 .

The results of the BMA analysis reported in Table 1 are obtained with the model prior set to $1 / 2^{k}$, where $k=21$, is the number of explanatory variables included in the model. The prior probability of the regression coefficients are constructed by using the Bayesian Information Criterion (BIC) for all the models. Moreover, the $\mathrm{MC}^{3}$ sampling employed is based on taking 1000000 draws, from which 100000 draws are discarded as burn-ins replications in order to obtain model and coefficient posteriors. Different model priors are used in order to obtain posterior parameter and model results. This is essential in order to ensure robustness and consistency of our results.

With the results presented on Table 1, the importance of the covariates in explaining school enrolment in Ghana is given by the Probability Inclusion Posterior (PIP) reported in the second column. The PIP shows the percentage of the model space wherein a covariate is included. The last two columns contain the posterior means and standard deviation for each regression parameter averaged across models. With these results, there is certainty that labour participation rate, household expenditure, the rate of progression to secondary school, pupil-teacher ratio, the rate of completion of primary school, labour force with primary education, percentage of female teachers in the community, the population growth rate are among the key variables that accurately explain school enrolment in Ghana.

Table 1. Bayesian model averaging results

\begin{tabular}{lccc}
\hline Variables & $\begin{array}{c}\text { Posterior Inclusion } \\
\text { Probability }\end{array}$ & Posterior mean & Posterior Standard deviation \\
\hline Intercept & 100.0 & 0.02149 & 164.8 \\
Progression rate to tertiary level & 24.1 & 0.7527 & 1.627 \\
HIV infection rate & 6.8 & -0.0000106 & 0.000445 \\
Life expectancy rate & 1.6 & 0.007621 & 0.06824 \\
GDP growth rate & 23.3 & 0.4135 & 0.8825 \\
Fertility rate & 71.7 & -2.060 & 1.500 \\
Parent education level & 65.9 & 0.01417 & 0.01257 \\
Household expenditure & 98.0 & -0.4910 & 0.1813 \\
\hline
\end{tabular}




\section{Macrothink}

Journal of Studies in Education

ISSN 2162-6952

2014, Vol. 4, No. 2

\begin{tabular}{|c|c|c|c|}
\hline Annual inflation rate & 1.9 & -0.000294 & 0.002813 \\
\hline Public spending on education & 69.5 & 0.4985 & 0.4443 \\
\hline Female household head & 29.9 & 1.773 & 4.737 \\
\hline Population growth rate & 89.5 & -2.739 & 1.443 \\
\hline Poverty level & 0.0 & 0.000 & 0.000 \\
\hline Primary school completion rate & 100.0 & 0.6199 & 0.1233 \\
\hline Percentage of female teachers & 41.9 & 0.00002845 & 0.00007477 \\
\hline Distance to school & 28.1 & 0.08961 & 0.1708 \\
\hline $\begin{array}{l}\text { Progression rate from secondary } \\
\text { to tertiary }\end{array}$ & 1.3 & 0.004196 & 0.04488 \\
\hline Infrastructure development & 61.7 & 0.8275 & 0.8234 \\
\hline pupil-teacher ratio & 98.2 & -0.9985 & 0.4085 \\
\hline Total repeater in primary & 0.0 & 0.000 & 0.000 \\
\hline Wealth of parent & 28.3 & 0.7178 & 1.238 \\
\hline $\begin{array}{l}\text { Progression rate to secondary } \\
\text { school }\end{array}$ & 100.0 & 0.1559 & 0.03618 \\
\hline Household size & 8.1 & 0.02506 & 0.1030 \\
\hline $\begin{array}{l}\text { Total number of teachers in the } \\
\text { community }\end{array}$ & 60.0 & 1.220 & 1.239 \\
\hline Cost of education & 95.6 & -1.230 & $5.459 \mathrm{e}-01$ \\
\hline Literacy rate & 42.8 & 1.757 & 3.471 \\
\hline $\begin{array}{l}\text { Percentage of male teachers in } \\
\text { the community }\end{array}$ & 13.7 & 0.05184 & 0.1596 \\
\hline Male headed household & 0.0 & 0.000 & 0.000 \\
\hline $\begin{array}{l}\text { Labour force with primary } \\
\text { education }\end{array}$ & 95.9 & 2.087 & 1.012 \\
\hline
\end{tabular}

Source: Authors' estimate

Moreover, there is a high degree of certainty that labour with primary education, household expenditure, the rate of progression to secondary school, pupil teacher ratio, the rate of completion of primary school, number of teachers in the community, percentage of female teachers in the community, distance of schools from the community, the population growth rate, parents' educational level and fertility rate have considerable impact in determining school enrolment, given the posterior inclusion probability and the statistical significance of their posterior means averaged over the model space. Nonetheless, the degree of certainty of variable inclusion in the model reduces for the rest of the variables. 
It is important to note that the BMA analysis aim at assessing the degree of certainty or uncertainty of specific variables to explain another variable of interest thus, determinants of school enrolment in Ghana in the case of this paper.

In order to gain insight into the degree of uncertainty that single models estimation could provide when assessing the determinants of school enrolment in Ghana, the results reported in Table 2 are compared with those in Table 1. Table 2 provides the results of the first five best single models, classified by the magnitude of the model posterior probability calculated from models visited by the $\mathrm{MC}^{3}$ algorithm. From Table 1, it is indicated that in model 1 the covariates are fertility rate, GDP growth, household expenditure, population growth, primary school completion rate, pupil teacher ratio, progression to secondary school, labour force with primary education and primary female teachers. In addition to explanatory variables for model 1, model 2 includes number of schools in the community, model 3 includes number of dependents, model 4 includes progression to secondary school by males and model 5 includes HIV infection rate. The results of the single models estimation reported in Table 2 indicates the degree of uncertainty related to choosing a specific model formulation in determining school enrolment.

In addition, choosing a single model can be misleading for policy formulation as per example, model 5 that indicates the importance of explanatory variables such as HIV infection rate, the wealth of the parents, total number of trained teachers in the school and GDP growth rate has the posterior model probability of less than $20 \%$. Thus, if policy makers would be basing their recommendation on such a model, they would be more than $80 \%$ sure it is not the correct model.

Based on the level of significance (at least 5\% level of significance) of the covariates averaged across model, the results of the BMA analysis reported in Table 1 shows the importance of covariates such as household expenditure, population growth rate, infrastructure development, pupil-teacher ratio, the rate of progression to secondary school, number of teachers, percentage of female teachers, distance of school from the community, parents' educational level, wealth of parents and the rate of primary school completion rate as the key factors in explaining school enrolment in Ghana. The negative sign of population growth rate, fertility rate and high household expenditure indicates the damaging effect the three factors have on school enrolment. High level of population growth rate is found to hamper school enrolment in Ghana. This reality is commensurate with the fact that increases in the population growth rate increase the number of pupils in each household. The increase in the number of children in each household leads to an increase in household expenditure which makes it difficult for them to have excess money to spend on children's education hence the low school enrolment.

In addition, parental education, household wealth, average distance to school, higher teacher -child ratio, lower pupil-teacher ratio, the rate of primary school completion rate, progression rate to secondary school, labour force with primary education and shorter distance to school are all significant and have a positive impact on enrollment. 
Table 2. Posterior means of the best five models

\begin{tabular}{|c|c|c|c|c|c|}
\hline Variables & Model 1 & Model 2 & Model 3 & Model 4 & Model 5 \\
\hline Intercept & $0.01833^{*}$ & $0.01710^{*}$ & $0.04992 *$ & $0.5400^{*}$ & $0.01848 *$ \\
\hline \multicolumn{6}{|l|}{ Progression to tertiary } \\
\hline \multicolumn{6}{|l|}{ HIV infection rate } \\
\hline \multicolumn{6}{|l|}{ Life expectancy rate } \\
\hline GDP growth rate & & & & & $1.880^{*}$ \\
\hline Fertility rate & $-2.138 *$ & $-2.116^{*}$ & $-3.883^{*}$ & $-2.993^{*}$ & \\
\hline Parent education level & -0.02707 & -0.02629 & & & 0.02442 \\
\hline Household expenditure & $0.5816^{*}$ & $0.5778^{*}$ & $0.4269 *$ & $0.4025^{*}$ & $0.55131 *$ \\
\hline \multicolumn{6}{|l|}{ Inflation rate } \\
\hline $\begin{array}{l}\text { Public spending on } \\
\text { education }\end{array}$ & & $0.5107^{*}$ & $0.7923 *$ & & $0.7216^{*}$ \\
\hline Female head & & & & 13.69 & \\
\hline Population growth & $-3.035^{*}$ & $-2.940^{*}$ & $-3.209^{*}$ & $-3.711^{*}$ & $-3.022 *$ \\
\hline \multicolumn{6}{|l|}{ Poverty } \\
\hline $\begin{array}{l}\text { Primary school } \\
\text { completion rate }\end{array}$ & $0.6070^{*}$ & $0.6286^{*}$ & $0.6422 *$ & $0.4694 *$ & $0.5451 *$ \\
\hline $\begin{array}{l}\text { Percentage of female } \\
\text { teachers }\end{array}$ & $-0.001367^{*}$ & $-0.001275^{*}$ & & & $-0.001042 *$ \\
\hline Distance to school & 0.3411 & 0.3359 & & & \\
\hline \multicolumn{6}{|l|}{$\begin{array}{l}\text { Progression from } \\
\text { secondary to tertiary }\end{array}$} \\
\hline \multicolumn{6}{|l|}{ Infrastructure } \\
\hline development & & & $1.420^{*}$ & & $1.150^{*}$ \\
\hline pupil-teacher ratio & $1.129 *$ & $1.080^{*}$ & $0.5731^{*}$ & $0.9741 *$ & $1.380^{*}$ \\
\hline \multicolumn{6}{|l|}{ Total repeater in primary } \\
\hline Wealth of parent & & & & & 2.380 \\
\hline $\begin{array}{l}\text { Progression rate to } \\
\text { secondary school }\end{array}$ & $0.1663^{*}$ & $0.1682 *$ & $0.1262 *$ & $0.1620^{*}$ & $0.1384^{*}$ \\
\hline \multicolumn{6}{|l|}{ Household size } \\
\hline $\begin{array}{l}\text { Total number of teachers } \\
\text { in the community }\end{array}$ & $2.410^{*}$ & $2.437 *$ & $1.724 *$ & & \\
\hline Cost of education & $-1.666^{*}$ & $-1.671^{*}$ & $-0.9350^{*}$ & $-1.236^{*}$ & $-1.452 *$ \\
\hline Literacy rate & & & $1.238^{*}$ & $1.030^{*}$ & $0.8277^{*}$ \\
\hline Percentage of male & & & & 0.4636 & \\
\hline
\end{tabular}




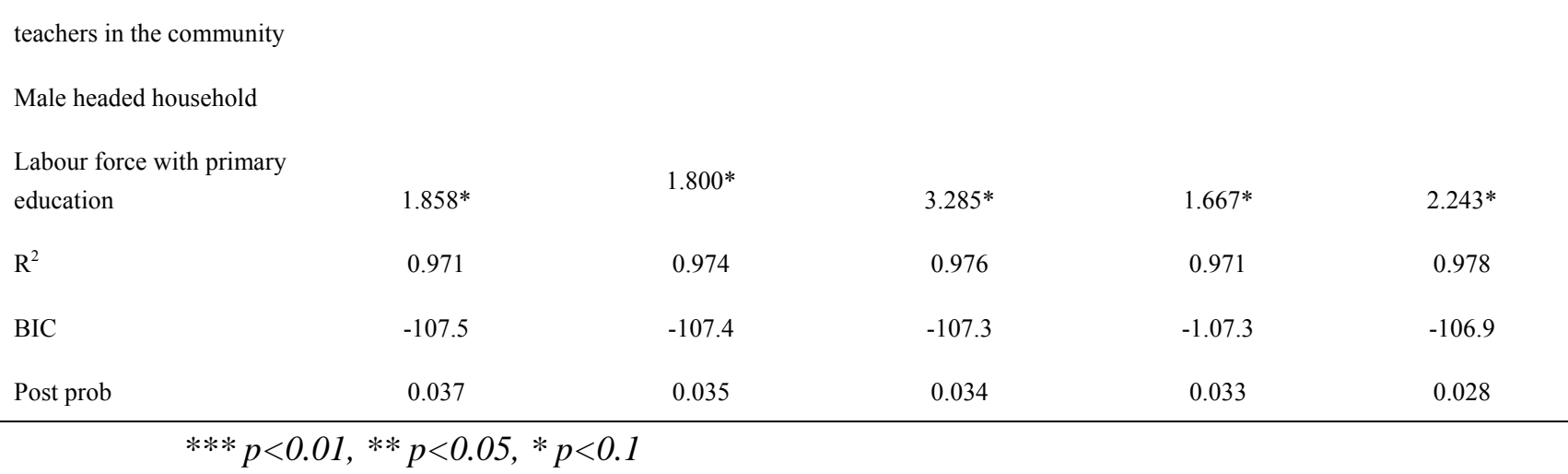

From the result, the education level of the parents and the resource level of the appear to have a significant effect on children's school enrolment. This means that as the educational level of the parents increases they are likely to be in employment and this combined effect has a positive impact of children being sent to school. The coefficient of the educational level variables are positive, thus indicating that parents with formal education tend to spend more on their children's education than parents with no formal education. This may be because as parents acquire more education, they tend to know the importance of education. This can be explain from the point that as parents achieve higher level of education, they tend to know the benefits associated with educating a child, therefore would enroll more in school. In addition, educated parents consider both the implicit and explicit benefits of investing in their children's education. As parents acquire more education, they tend to realise the implicit benefit associated to child education. For example sending a child to school gives them some psychological satisfaction compared to parents with low level of education. Kirchsteiger and Sebald (2010) found that parents' preference for spending on children's education is determined by the parents' educational level. Pasqua (2005) studied gender bias in parental investment and found out that the educational level reached by parents plays an important role in their decision on how much to spend on their children's education, especially with respect to the sex of the children. Thus, this study has confirmed that Ghanaian parents' educational level determines the average expenditure made on a child's education.

The pupil-teacher ratio is significant and negatively influences the level of school enrolment in Ghana. This means that when the pupil-teacher ratio is higher, fewer pupils are enrolled in schools and vice versa. The possible reason being that as the ratio of the pupil to teacher is high increases, teachers tend not to have attention for the children and this means that the performance of the children will be low. The low performance of the pupil normally discourages the parents to use their resources to send children to school but rather prefer they use them in their household duties. This relationship between pupil-teacher ratio and school enrolment was confirm in the work of Huisman and Smits (2009) who studied the effects of household and district level factors on primary school enrolment in developing country.

In addition, the total number of teachers available in schools in the community tends to influence school enrolment in Ghana. In areas where schools do not to have enough teachers, parent are discouraged from sending their children to school as they consider it as 
waste of resources and time to send their children to school without teachers available to teach them. This positive correlation between the number of teachers and school enrolment is in conformity with the works of Edmonds (2006), Ersado (2005) and Thorbecke and Charumilind (2002).

Beside the total number of teacher found to influence school enrolment in Ghana, the percentage of female teachers at the primary level was also found to have a positive effect on school enrolment. This means that parents tend to have more trust to keep their little ones with female teachers than the male teachers. Generally female teachers are considered to be more caring than their male counterpart. Therefore, in situations where we have more female teachers, parents tend to enroll their children in schools as they believe the child will have the same level of care even as with them at home. This finding is in line with Huisman and Smits (2009), who also found percentage of female teachers to influence school enrolment in 30 developing countries.

The study also considered the number of schools in the community. It is expected that the number of primary schools in the community and the number of children parents enroll in school are positively related. This means that if the number of primary schools in the community is high, more of the children are likely to be enrolled in school. In addition, more schools in the community means the distance from the schools to the house/home is likely to be shorter and this means that parents will not incur additional cost such as transportation cost to send their children to school hence increasing the school enrolment of children. This finding is in line with Huisman and Smits (2009), Pritchett and Filmer (1999) and Kirchsteiger and Sebald (2010) and Lang and Ruud (1986) who found distance from school to influence school enrolment.

From the results in Table 1, labour force with primary education has been found to be significant and positively correlated with school enrolment. This means that if parents found that with completion of primary education, their children can get a job in the job market, they will be motivated to enroll them in school. Thus, the higher the parents perceive that their children will get jobs in the future with even primary level qualification, the higher would be the investment in their education and vice versa. As in the works of Bennel (1996) and Foltz and Gajigo (2007), education is considered an investment and parents invest in their children's education if the benefits exceed the cost.

Also, the rate of progression to secondary school level is found to be significant and positively related to school enrolment in Ghana. This means that as parent realizes that their children have a greater chance of continuing their education due to availability of schools, they are encouraged to send them to primary school. However, if parents find out that after primary education, there is no opportunity for their children to further their education to secondary school, they would be discouraged to enrol them in primary school. This finding from the study is in line with the study of Emerson and Portela (2007)

The result from the study also reveals that public spending on education is significant and directly related to school enrolment. This means that as public expenditure on education increases, the number of children enrolled in school also increases. In Ghana, the government 
has introduced various programmes such as school feeding programmes and free uniform distribution among others. The introduction of these programmes saw government expenditure on education increasing. These programmes in effect are encouraging most parents in Ghana to enrol their children in school as revealed in the study.

\section{Concluding Comments}

The main aim of this study was to address the issue of model uncertainty associated with previous studies in determining factors that influence school enrolment in Ghana by adopting the Bayesian moving average as well as carrying out the empirical studies over a longer sample period of 1970-2012.Infrastructure development, pupil-teacher ratio, the rate of progression to secondary school, number of teachers, percentage of female teachers, distance of school from the community, parents' educational level and the rate of primary school completion are found to be significant and positively related to school enrolment in Ghana.

In addition, household expenditure, population growth rate and fertility rate are significant and negatively correlated to school enrolment. To encourage school enrolment, government should introduce the quota system where more females will be train as teachers as compared to their male counterparts. In addition, government should reduce the distance travel to school by building schools in each community as this will encourage parents to enroll their children in school.

Also, family planning policies should be encouraged to reduce fertility rate and population growth rate. This will also help to reduce household expenditure on consumption and in effect encourage parent to invest in their children's education. Finally, future research on this issue should consider the possibility of exploring the TVP-VAR model in order to cater for time variations in the data.

\section{References}

Basu, K. (1999). Child labor: Cause, consequence, and cure, with remarks on international labor standards. Journal of Economic Literature, 37(3), 1083-1119. http://dx.doi.org/10.1257/jel.37.3.1083

Becker, G. S., \& Tomes, N. (1976). Child endowments and the quantity and quality of children. Journal of Political Economy, 84(4), 143-162. http://dx.doi.org/10.1086/260536

Bennel, P. (1996). Rates of return to schooling: Does the conventional pattern prevail in sub-Saharan Africa? World Development, 24(1), 183-199. http://dx.doi.org/10.1016/0305-750X(95)00115-S

Buchmann, C., \& Brakewood, D. (2000). Labor structure and school enrolments in developing societies: Thailand and Kenya compared. Comparative Education Review, 44(2), 175 204. http://dx.doi.org/10.1086/447602

Colclough, C., Pauline, R., \& Tembon, M. (2000). Gender inequalities in primary schooling: The roles of poverty and adverse cultural practice. International Journal of Educational Development, 20(1), 5-27. http://dx.doi.org/10.1016/S0738-0593(99)00046-2 
Connelly, R., \& Zhen, Z. (2003). Determinants of school enrolment and completion of 10 to 18 year olds in China. Economics of Education Review, 22(4), 379-388 http://dx.doi.org/10.1016/S0272-7757(02)00058-4

Dickens W. T., Sawhill I., \& Tebbs J. (2006). The effects of investing in early education on economic growth.. Policy Brief No. 153, Brookings Institutions, Washington, DC.

Edmonds, E. V. (2006). Does child labor decline with improving economic status? Journal of Human Resources, 40(1), 77-99.

Emerson, P. M., \& Portela S., A. (2007), Is Child Labor Harmful? The Impact of Working Earlier in Life on Adult Earnings, IZA Discussion Papers 3027, Institute for the Study of Labor (IZA).

Ersado, L. (2005). Child labor and schooling decisions in urban and rural areas: Comparative evidence from Nepal, Peru and Zimbabwe. World Development, 33(3), 455-480. http://dx.doi.org/10.1016/j.worlddev.2004.09.009

Fernandez, C., Ley, E., \& Steel, M. (2001), 'Model uncertainty in cross-country growth regressions', Journal of Applied Econometrics 16(5), 563-576. http://dx.doi.org/10.1002/jae.623

Filmer, D. (1999). The structure of social disparities in education: Gender and wealth (Policy research working paper No. 2268). Washington: The World Bank.

Foltz, J. D., \& Gajigo, O. (2007). Assessing the returns to education in the Gambia. Journal of African Economies, 21(4), 580-608. http://dx.doi.org/10.1093/jae/ejs003

Glewwe, P., \& Jacoby, H. (1994), Student achievement and schooling choice in low-income countries. Evidence from Ghana. Journal of human resources, 844-864

Glick, P., \& Sahn, D. E. (2000). Schooling of girls and boys in a West African country: The effects of parental education, income, and household structure. Economics of Education Review, 19, 63-87 http://dx.doi.org/10.1016/S0272-7757(99)00029-1

Huisman, J., \& Smit, J. (2009). Effects of household- and district-level factors on primary school enrolment in 30 developing countries. World Development, 37(1), 179-191. http://dx.doi.org/10.1016/j.worlddev.2008.01.007

Kirchsteiger, G., \& Sebald, A. (2010). Investments into education: Doing as the parents did. European Economic Review, 54(4), 501-516. http://dx.doi.org/10.1016/j.euroecorev.2009.09.004

Lang, K., \& Ruud, P. A. (1986). Returns to schooling implicit discount rates and black-white wage differential. The Review of Economic Statistics, 68(1), 41-47. http://dx.doi.org/10.2307/1924926

Lloyd, C. B., \& Blanc, A. K. (1996). Children's schooling in sub-Saharan Africa: The role of fathers, mothers, and others. Population and Development Review, 22(2), 265-298. http://dx.doi.org/10.2307/2137435 


\section{Macrothink}

Journal of Studies in Education

ISSN 2162-6952 2014, Vol. 4, No. 2

Måns, S., Teal, F. J., \& Wambugu, A. (2006). The dynamics of return to education in Kenyan and Tanzanian manufacturing. Oxford Bulletin of Economics And Statistics, 68(3), 261-288. http://dx.doi.org/10.1111/j.1468-0084.2006.00162.x

Mutangadura, G., \& Lamb, V (2003).Variations in rates of primary school accessand enrolments in sub-Saharan Africa: a pooled cross-country time series analysis. International Journal of Educational Development, 369-380. http://dx.doi.org/10.1016/S0738-0593(02)00060-3

Pasqua, S. (2005). Gender bias in parental investments in children's education: A theoretical analysis. Review of Economics of the Household, 3(3), 291-314. http://dx.doi.org/10.1007/s11150-005-3459-x

Raftery, A.E., D. Madigan, \& Hoeting, J. A. (1997). Bayesian Model Averaging for Linear Regression Models,. Journal of the American Statistical Association, 92, 179-191. http://dx.doi.org/10.1080/01621459.1997.10473615

Schultz, T.W. (1961). Investments in human capital. American Economic Review, 51(1), $1-17$.

Schultz, T. P. (1993). Investments in the schooling and health of women and men: quantities and returns. Journal of Human Resources, 28 (4), 694-734. http://dx.doi.org/10.2307/146291

Smits, J., \& Gündüz-Hoşgör, A (2006). Effects of family background characteristics on educational participation in Turkey. International Journal of Educational Development, 26(5), 545-560. http://dx.doi.org/10.1016/j.ijedudev.2006.02.002

Thorbecke, E., \& Charumilind, C. (2002). Economic inequality and its socioeconomic impact. World Development, 30(9), 1477-1495. http://dx.doi.org/10.1016/S0305-750X(02)00052-9

United Nations Educational, Scientific and Cultural Organization (UNESCO) (2004). Education for all: The quality imperative. Paris: United Nations Educational, Scientific and Cultural Organization. 


\section{Appendix}

Table A2: Summary Statistics of Determinants of School Enrolment 1970-2012

\begin{tabular}{|c|c|c|c|c|}
\hline Variables & Mean & Std dev & Min & $\max$ \\
\hline Total school enrolment rate & 59.600 & 1.975 & 38 & 91.070 \\
\hline GDP growth rate & 0.012 & 0.162 & -1 & 0.142 \\
\hline public spending on education per GDP & 2.887 & 3.003 & 0.649 & 12.290 \\
\hline HIV infection rate & 2.514 & 0.023 & 0.912 & 3.950 \\
\hline Life expectancy rate & 57.911 & 4.813 & 42.542 & 126.980 \\
\hline Annual inflation rate & 39.518 & 7.298 & 9.00 & 126.000 \\
\hline Fertility rate & 5.073 & 1.527 & 2.049 & 7.197 \\
\hline Progression to tertiary level & 3.098 & 1.032 & 1.054 & 5.876 \\
\hline Parents education level & 47.090 & 0.044 & 40.531 & 99.430 \\
\hline Household expenditure & 3.397 & 1.302 & 1.718 & 7.404 \\
\hline Female heads household & 15.251 & 7.201 & 3.531 & 29.002 \\
\hline Population growth & 2.760 & 0.030 & 1.900 & 3.930 \\
\hline Poverty level & 5.630 & 2.380 & 5.087 & 10.870 \\
\hline Primary school completed & 67.748 & 21.269 & 37.783 & 109.080 \\
\hline Percentage of female teachers & 23.075 & 11.797 & 3.338 & 48.802 \\
\hline Distance from school & 8.667 & 2.450 & 2.269 & 4.667 \\
\hline Infrastructure development & 8.148 & 2.469 & 4.517 & 12.250 \\
\hline Pupil teacher ratio & 59.715 & 31.288 & 25.440 & 128.120 \\
\hline Total repeaters in primary school & 7.931 & 4.845 & 1.542 & 16.116 \\
\hline Wealth of parents & 13.769 & 6.045 & 1.151 & 34.334 \\
\hline Progression to secondary school & 43.940 & 2.760 & 24.820 & 98.070 \\
\hline
\end{tabular}

